\title{
ОПЫТ СОВМЕСТНОЙ ОБРАБОТКИ И ИНТЕРПРЕТАЦИИ МОРСКИХ И СУХОПУТНЫХ ДАННЫХ МОВ ОГТ В СЕВЕРНОЙ ЧАСТИ ТИМАНО-ПЕЧОРСКОЙ НЕФТЕГАЗОНОСНОЙ ПРОВИНЦИИ
}

\author{
Вискунова К.Г., Кунько А.Л., Лавренова Т.В., Кузнечова И.Ф.
}

(ОАО «Нарьян-Марсейсморазведка»)

В докладе анализируются результаты полевых (морских и сухопутньх) поисковых и опытнометодических сейсморазведочных работ МОВ ОГТ $2 \mathrm{D}$, результаты переобработки профилей прошльх лет и их совместной интерпретации. Обосновывается оптимальная система наблюдений в транзитной зоне, демонстрируется увязка морских и наземных наблюдений. Основная геологическая задача работ состояла в изучении строения нефтегазоперспективных объектов зоны сочленения Печоро-Колвинского авлакогена и Хорейверской впадины. В работе использовались современные программные обрабатывающие и интерпретационные комплексы. Стратиграфическая привязка ОГ к разрезам сухопутных и морских скважин проводилась по материалам ВСП и ГИС. При интерпретации применялись общепринятые методики палеотектонического и сейсмофациального анализов. Целевыми интервалами разреза рассматривались отложения силура, девона и нижней перми.

Большинство известных залежей в прилегающей сухопутной части провинции связано с отложениями верхнекаменноугольно-нижнепермского карбонатного комплекса (Хыльчуюскре, ЮжноХыльчуюское, Ярейюское, Поморское).

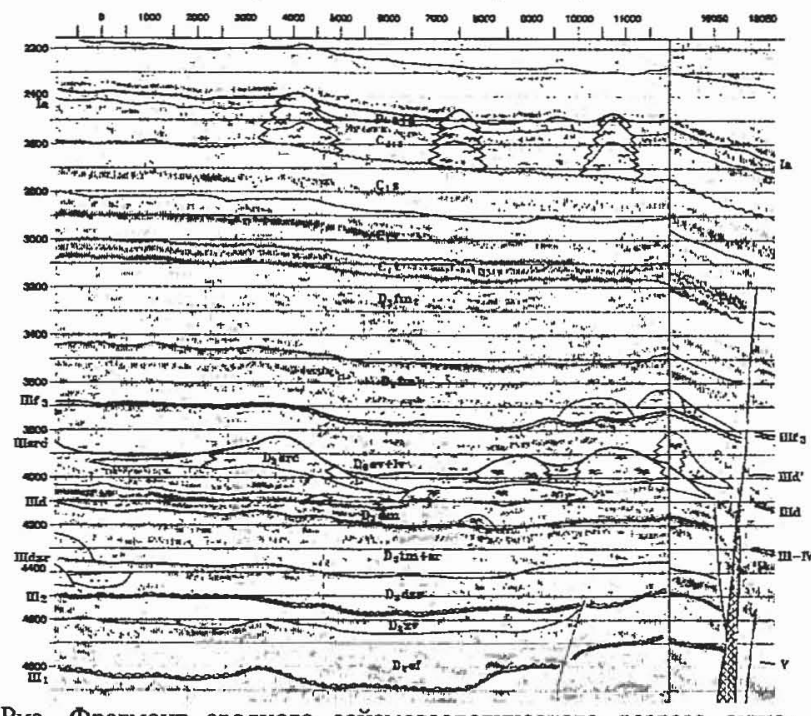

Рис. Фрагмент сводного сейсмогеологиеского разреза сушамope

В этой части разреза в морской и сухопутной qастях ТПП намечены зоны распространения рифогенных построек (Рис.1) и сопутствующих им толщ облекания. Все перспективные локальные объекты антиклинальные и являются мелкими по величине ресурсов.

В верхнедевонской части разреза вблизи участка работ залежи нефти известны в Хорейверской впадине (Табровояхинское месторождение) и в Печоро-Колвинском авлакогене (Инзырейское месторождение) и связаны с карбонатными коллекторами различного генезиса. Наиболее уверенно в волновом сейсмическом поле выражкены органогенные по- стройки сирачойского и нижнефаменского возраста. Объекты в этой части разреза характеризуются небольшими размерами и соответственно мелкими ресурсами нефти.

Более $80 \%$ извлекаемых ресурсов нефти изучаемой площади связано с терригенными коллекторами, развитыми в поддоманиковых отложениях. Локализованы зоны выклинивания (срезания) верхнедевонских джъерских, среднедевонских живетских и эйфельских, нижнедевонских отложений, в пределах которых оконтурены литологостратиграфические и тектонически экранированные неантиклиналные ловушки. Рисунок сейсмияеской записи, в целом, крайне изменгив по площади, конфигурация отражений меняется от хаотической и линзовидной, волнистой до непрерывной и амплитудной. Поддоманиковый интервал разреза насыпен многочисленными разноамплитудными разломами, затрудняющими отождествление отражений в соседних блоках. В разрезе прослеживается несколько поверхностей несогласия. Наиболее уверенно выделяется угловое несогласие в кровле среднедевонских отложений. В подопве комплекса отмечается подошвенное налегание. Сверху отложения среднего девона-джъера перекрываются тиманскосаргаевской региональной покрышкой. Глубины залегания объектов, как правило, более $4000 \mathrm{M}$.

К югу от изучаемой территории эйфельские отложения являются продуктивными на Ольгинской плошади, живетские и джъерские - на ВосточноЯрейюской и Восточно-Сарутаюской площадях.

Малоамплитудные объекты изучаемой северной (морской и сухопутной) части ТПП являются основой будушего прироста запасов нефти. Учитывая слабую изученность этой части провинщии обосновываются рекомендации на проведение работ MOB ОГТ 2D, предназначенные для выбора первоочередных объектов для поисково-оценочного бурения. 